Nadwa : Jurnal Pendidikan Islam

Vol. 13, No.2 (2019)

Accredited by Ristekdikti based on Decree No. 51/E/KPT/2017

DOI : $\underline{10.21580 / \mathrm{nw} .2019 .13 .2 .5870}$

\title{
Maximizing Religious Capital: Building English Villages Based on Islamic Education around the Campus
}

\section{Muhammad Saifullah}

Email: say_full2003@yahoo.com

UIN Walisongo Semarang

\section{Sofa Muthohar}

Email.sofamuthohar@walisongo.ac.id

UIN Walisongo Semarang

\section{Sayyidatul Fadlilah}

Email: sayyidatulfadlilah@ gmail.com

UIN Walisongo Semarang

\begin{abstract}
Some Islamic groups, especially the traditional Indonesian circles, have a negative view of English. English is considered the language of infidel invaders and the language of hell. This paper aims to describe the development of society in implementing Islamic religious education while eliminating the negative impression of the use of English in Islamic societies to be an important language to be learned as a language of global communication. The research method uses the sociological phenomenological method. The results showed that the Amanah village had six social capital namely human capital, social capital, natural capital, physical capital and financial capital and religious capital. The development strategy undertaken is to maximize religious capital by establishing religious institutions and carrying out religious activities by being given English language lessons. There are two centers of activity, namely the Baitussalam mosque and the AleC (Amanah Learning Center). Other capital that plays a significant role is social capital that is inclusive and accommodating towards migrants.
\end{abstract}

Keywords: Islamic Religious Education; kampoeng amanah; English; global; religious capital; inclusive; accommodating;

\section{Abstrak}

Sebagian masyarat Islam terutama kalangan tradisional Indonesia berpandangan negative terhadap bahasa Inggris. Bahsa inggris dianggap sebagai bahasa para penjajah yang kafir dan bahasa neraka. Tulisan ini bertujuan untuk menggambarkan pembangunan masyarakat dalam melaksanakan pendidikan 
Agama Islam sekaligus menghilangkan kesan negative penggunaan bahasa Inggris di masyarakat Islam menjadi bahasa penting untuk dipelajari sebagai bahasa komunikasi global. Metode penelitian menggunakan metode fenomenologis sosiologis. Hasil penelitian menunjukkan bahwa kampung Amanah memiliki enam modal sosial yaitu human capital, social capital, natural capital, physical capital dan financial capital serta religious capital. Strategi pembangunan yang dilakukan yaitu dengan memaksimalkan modal relgius dengan mendirikan institusi agama dan menjalankan kegiatan-kegiatan agama dengan diberi sisipan pelajaran bahasa Inggris. Pusat kegiatan ada dua yaitu masjid baitussalam dan AleC (Amanah Learning Center). Modal lain yang sangat berperan adalah modal sosial masyarakat yang bersikap inklusif dan akomodatif terhadap para pendatang.

Kata kunci : Pendidikan Agama Islam; kampoeng amanah; bahasa inggris; religious capital; inklusif; akomodatif;

\section{Preface}

The existence of the 'Village of Education based on Religious Education' in supporting the improvement of students' ability in English is very urgent in the global era. The opinion spread among some traditional Indonesian Muslims that English is the language of infidels (non-Muslims). That opinion is an ideological obstacle for young generations of Islam to study English actively. Statements have even developed that Arabic is the language of heaven while English is the language of hell, so avoid it. The situation has changed now when compared to the colonial period in Indonesia, where English is a world language. Almost all countries recognize and use English as a second or third language in communication. It was very necessary for community groups to use English based on Islamic religious education to open up the horizons of the Islamic community thought about the importance of English as a language of communication in the global era. 
This study aims to provide an overview of strategies to build integration between Islamic Religious Education with the process of building the British community in the campus (urban) environment. This process shows how difficult to build a religious community in urban areas by maximizing the ability of the community in the field of religion and at the same time building a positive perception about the use of English as a language of communication in the midst of an urban Islamic society. Sociologically, maximizing religious capital have brought positive perceptions and influenced community activities to building the progress of the Amanah village. Other capital that supports this development is social capital, which has an accommodative and openness towards migrants.

The success of this development can support the needs of the campus to creat academic culture. On the other hand, it was fulfill the demands of the world of work in the era of the Asean Economic Community (AEC). The success in building the British community in Indonesia built in Kampung Pare Kediri, Indonesia. There was one of the destinations of British villages, which has more than 75 language course institutions. 12

\section{Research methods}

This study took place in the Amanah village Jl. Taman Karonsih Raya Ngaliyan Village Ngaliyan District Semarang City. This research is a field research with a qualitative approach. The aim of this approach is to describe the potential of the Amanah village as

\footnotetext{
1 Danus Ardiansah, "Kampung Bahasa Sebagai City Branding Kota Pare Kediri: Studi Kualitatif Komunikasi Pemerintah Kabupaten Kediri” (UIN Sunan Ampel Surabaya, 2014).

2 Sindy Wulandari, "Perubahan Sosial di Kampung Inggris : Studi Kasus Dusun Singgahan Desa Pelem Kecamatan pare kabupaten Kediri," 2015, http://digilib.uinsby.ac.id/2176/6/Bab\%203.pdf.
} 
an English village based on religious values. The data used in this study consisted of primary data and secondary data.

The method of finding data is environmental observation both physical and non-physical. a questionnaire used to find out the community's understanding of the village capital of Amanah and various expectations in the future so that it can be seen and analyzed in accordance with religious values and capital. That can be collaborated with other parties according to the principle of building language community. Interview method used to find primary sources about the community with the idea of the English village; Focus group Discussion used to find out the facts of the village capital of Amanah and at the same time as confirmation, expert judgment and data triangulation. The sampling method in this study uses purposive stratified random sampling. Namely sampling in accordance with research objectives in a structured manner, community leaders and the most competent parties. After the data has been collected, then analyzed using an interpretive framework of symbolic interactionism aproach. 3

\section{Community Capital Development}

Society has very diverse social capital depending on the complexity of the community and its environment. The Department for International Development (DFID) of the United Kingdom compiled a guidebook for the empowerment of the international community. The book used as a guide for empowering various countries in the world --- including Indonesia, --- in the Sustainable Livelihoods Guidance Sheets. Guidelines stipulate that the main factor for determining livelihoods or people's livelihood

3 Norman K Denzin dan Yvonna S Lincoln, Handbook Of Qualitative Research, 1 ed. (Yogyakarta: Pustaka Pelajar, 2009), vi. 
determined by the Asset Pentagon. 4 The five things that make up a pentagonal line are

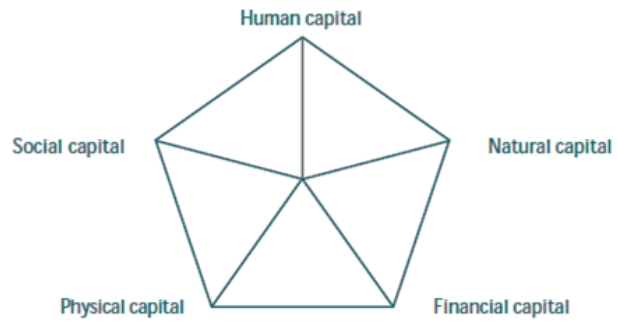

First, Human capital, is something that belongs to humans individually, for example skills, knowledge, ability to work and good health. All of these things make a person can carry out efforts to achieve their goals. Human capital is a key capital that can move other capital to achieve maximum goals. To be able to maximize this human capital, it is necessary to know in advance the problems and obstacles faced, usually the problems of education, health, ability, confidence and motivation.

Second, Social capital (community capital). In the social empowerment context, social capital is social resources that people can use to achieve goals. These social resources can include networking and relationships, both vertical (client) or horizontal (between individuals with shared interests); formal group membership that often requires compliance with rules, norms and sanctions that are mutually agreed upon or generally accepted, trust relationships, facilitate mutual cooperation, reduce transaction costs and protect each other. Social capital is important, especially

4 DFID, "Sustainable Livelihoods Guidance Sheets," 1999, 2.3.1, http://www.livelihoodscentre.org/documents/20720/100145/Sustainable+liveli hoods+guidance+sheets/8f35b59f-8207-43fc-8b99-df75d3000e86. 
with respect to mutual trust. The existence of public trust can directly affect the increasingly low cost. Effective communication with existing social capital can reduce costs and make work effective and reduce the risk of problems, especially to the use of shared goods or facilities. The form of social capital maximization can be by streamlining relations or even transforming social structures into new structures that are more open and support the achievement of goals. 5 Modern organizations driven using rules. They set clear work procedures and responsibilities for making decisions and determined by their positions and responsibilities than by individual influences. However, in reality people who want service often ignore the procedure. When they want to get a job, they often ignore bureaucratic procedures and take shortcuts by calling up trusted friends, close acquaintances or relatives. Therefore, the network is very important and real. It is not a matter of how many people are known but who is known. Social capital is then interpreted as a social network that means part of the network and relationships that help a person in achieving goals and serve as a social bond. 6 Antony Gidden, a British sociologist who is famous for his social structure theory, as quoted by John Field, said that structure is always between enabling and forcing good in relation to structure and agency. 7 Therefore, in a network, a person sometimes can use the network and at other times, he is used and pressured by others to follow the organization rules.

Third, Natural capital. The natural capital is a term used to indicate the availability of natural resources and services that can be used to achieve empowerment goals. These natural resources include natural capital, both physical and non-physical resources such as the atmosphere and other biodiversity. Who are own natural

5 DFID, 2.3.2.

6 John Field, Social Capital (London; New York: Routledge, 2003), 3.

7 Field, Social Capital, 3. 
resources? Who controls? Moreover, how people can access them? - is a question that can be used to recognizing this natural capital. This is important, because it is often associated with public health, which is certainly very expensive. Conversely, if natural resources are lacking, humans will tend to suffer and get sick, especially in areas where the air quality is poor coused of industrial activities or natural disasters. 8 The thing that needs to be done on this natural resource is how to keep this resource for last longer and good to be utilized.

Fourth, Physical Capital. Physical capital consists of basic infrastructure and production goods needed for social development. Infrastructure consists of an environment that helps people to meet basic needs. Whereas producer goods are tools and equipment that are useful to help people to be more productive. Important infrastructure components for a sustainable program are (a) affordable transportation; (b). Protection and safe building; (c). Adequate water supply and sanitation; (c). Clean and affordable energy; and (d) access to information (communication). Infrastructure is generally a public good used without direct payment. There are exceptions to the place of residence, which is often privately owned, and some other paid infrastructure (for example toll roads and energy supplies, hospitals, places of education), producer goods can be owned by individuals or groups on a basis or accessed through rent or 'fees for services'. The availability of physical capital is related to creating ease of society in finding the necessities of life, comfort living, supporting effectiveness and high productivity. 9

Fifth, Financial capital. Financial capital is a financial resource that people use to achieve their goals. There are two main sources of financial capital, namely (a). The available stock such as

8 DFID, "Sustainable Livelihoods Guidance Sheets," 2.3,3.

9 DFID, 2.3.4. 


\section{4 | Muhammad Saifullah at,all}

savings. These savings can take various forms such as cash, bank deposits or liquid assets such as livestock and jewelry. Financial resources can also be obtained through lending institutions. (b). Regular cash inflows such as pension funds, or other income from the state, and remittances. (modal keuangan). Financial capital is the most versatile and flexible of the five asset categories. This can be converted with various levels of convenience into other types of capital, it can be used to directly achieve goals such as buying food to reduce food insecurity. Maybe right or wrong, money can also be turned into political influence and can encourage people to participate more actively in formulating policies and laws governing access to resources. 10

There is a term that might confuse human capital with social capital. The 2001 Organization for Economic Co-operation and Development (OECD) report clearly distinguishes these two terms. Human capital is manifested in individual abilities while social capital is manifested in social and political, institutional and legal relations. 11

In reality, pentagonal assets can take different forms. There are people who are strong in their human capital, but weak in other fields, some are strong in the field of natural capital but weak in their social capital. In mapping, social capital will be able to give an idea of which side of the capital is weak and will be empowered and which capital is strong to sustain. Assets owned by a community, are not always in a balanced position between the five capitals. Balance patterns can take various forms, for example:

10 DFID, 2.3.5.

11 Asian Productivity Organization, Potential of Social Capital for Community Development (Japan: APO, 2006), 11. 

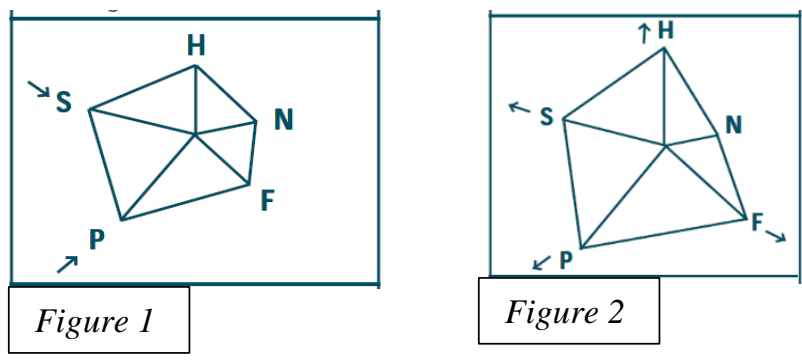

Balance Patterns 12

Figure 1 shows the position of human capital, natural capital and financial capital in a weak position while social capital and physical capital in a strong position. The urban poor often experience such conditions where the infrastructure and the community are already well established and educated, but they are unable to access, use them, and enjoy them. They are precisely in a pressured position by circumstances. Usually this is due to lack of education, knowledge and lack of capital. Whereas Figure 2 shows different circumstances. The situation where there has been a strengthening of human capital and financial capital so that they can use social capital and physical capital as strengths. The community can experience figure 2 after empowerment, through increased education, skills training or capital provision.

Historically, the community empowerment program emerged as a form of criticism of the concept of development using the approach to economic growth as many 'refer' to the United States and are top down, tricle down effect. Although there are successes such as in China, various research results that examine the implementation of poverty alleviation programs and community empowerment mention that the success of these programs, according to Agus (2009), quoting Muktasam (2001) Chambers

12 DFID, "Sustainable Livelihoods Guidance Sheets," 2.3. 
(1983), Harrison (1995), Burkey (1993), Esman and Uphoff (1984). Based on the experience of the experts in the process of rural development and poverty alleviation programs in Asian and African countries, it was concluded that there are five main factors causing the failure of poverty alleviation programs were: (a). Because of the 'target' and 'top-down' approach; (b). Neglect of local values and 'outsiders' bias; (c). Lack of participation; (d). Non-holistic approach; and (e). Illusion of investment.13

Empowerment is a medium and long-term program, sustainable and whole, so that the results are seen with changes in community behavior that is increasingly participatory, productive and independent. Sometimes it cannot be measured with economic indicators for a moment and in a short time, in contrast to the concept of development that uses crashed programs that are shortterm, temporal and partial.14

In general, the purpose of empowerment is to improve the welfare of the community in the economic field, but this is a mistake, because the economy cannot stand-alone. Empowerment is defined as making the community empowered to use its potential in order to increase productivity, which affects the level of family welfare. In other fields, the term empowerment can be used for example in the fields of culture and education. Then empowerment can have a goal to empower people who did not know to know and who knew to be better. Guide the community to see what is lacking and then guide it to develop and have competitiveness. This is appropriate to empower urban communities with good facilities, but some communities are still weak. They are a forgotten society. Behind the sparkling and advancing development in the city,

\footnotetext{
13 Agus Purbathin Hadi, "Tinjauan terhadap berbagai program pemberdayaan masyarakat di indonesia," Yayasan Agribisnis/Pusat Pengembangan Masyarakat Agrikarya (PPMA), 2009.

14 Hadi.
} 
tucked into the urban poor. They have a unique culture (culture of modern poverty) 15 even sometimes accused as a source of unrest. 16 They are sometimes isolated in the crowd, crying amid smiles, silent in their inability and surrounded by well-off neighbors. They need to be raised from adversity and broken from the chain of incompetence. They need many help, not only funding, but also opportunities to change less productive cultures and behaviors into productive cultures. Thus, the purpose of community empowerment is not only improvement in the economic field, but also the field of work culture that is productive, participatory social, dynamic religion and conducive politics. It requires the construction of "social knowledge", especially regarding capital owned and not owned.17

Efforts to empower people (empowering) can be assessed from three aspects: (1). Enabling to create an atmosphere that allows the potential of the community to develop. (2). Empowering to strengthen the potential of the community, opening various opportunities for the community to become more empowered. (3). Protecting to protect the weak community.18 The important thing, as McTaggart argues, Alice stated that it is important in community empowerment that there is community participation not only involvement - in terms of conceptualization,

15 Godfried Engbersen, Cultures of Unemployment: A Comparative Look at Long-Term Unemployment and Urban Poverty (Amsterdam: Amsterdam University Press, 2006), 177.

16 William C. Bailey, "Poverty, Inequality, and City Homicide Rates. Some Not So Unexpected Findings," Criminology 22, no. 4 (November 1984): 581, https://doi.org/10.1111/j.1745-9125.1984.tb00314.x.

17 Nan Lin, Karen S. Cook, dan Ronald S. Burt, ed., Social capital: theory and research, Sociology and economics (New York: Aldine de Gruyter, 2001).

18 Munawar Noor, "PEMBERDAYAAN MASYARAKAT," Civis, no. 2 (2011): 13. 
implementation and reinforcement to be part of the lifestyle.19 With the participation of the community, there will be a sense of responsibility towards ideas and working hard to become reality.

\section{Development of Kampoeng Amanah as a British Village Based on Islamic Religious Education}

Kampung Inggris is a village community that have an environment to supports the development of English. The support is in the form of social or environmental patterns that make it easy for the community to access learning resources. Social support can be in the form of community support to communicate using English such as greetings, casual chat, and chat on community social media or courses. With the social support of the community and physical support of the environment, the community will get used to using English 24 hours a day. Thus, it will form an English mindset with native logic where the use of English without translation. People can already use language spontaneously. Various learning methods as used in the English village of Pare Kediri. More than 75 course institutions use different learning methods. These methods can be drilling (memorization method and repeated continuously) especially in the addition of vocabulary, singing, debating, playing games and outing classes (playing outside the classroom). 20

Meanwhile, "Kampoeng Amanah" is a village in the Rukun Warga (RW) 04 Ngaliyan Village, Semarang City, Indonesia. The naming of the village stems from the existence of the RW management commitment to develop its territory into an advanced region so that the RW management is named "Amanah Cabinet". The potential possessed by the Amanah village as an English village based on Islamic education, using the Five Capital analysis covers can be described as follows:

19 Alice McIntyre, Participatory action research, Qualitative research methods 52 (Los Angeles: Sage Publications, 2008), 15.

20 Nurmala Hendrawaty dan Tri Angkarini, "THE ACQUISITION OF ENGLISH AS A FOREIGN LANGUAGE IN PARE EAST JAVA (KAMPUNG INGGRIS)," Deiksis 05 (2013): 8. 
First, Human capital. In the trust village, there are student groups and community groups. From the student group there were 102 people, and youth groups of about 35 people. They 95\% participated in the construction of a village of trust to become a British village. The population of the Kampoeng Amanah community is 243 families with a population of 856 people). The average level of education is High School (SMA). Some people have received master and doctoral education. They include teachers, and lecturers at UIN Walisongo. There are also several Masters Students.21

Second, Natural capital. Kampung amanah has a strategic geographical location of 2 kilometers near the UIN Walisongo campus. About $10 \mathrm{~km}$ from Semarang Ahmad Yani International Airport. 15 kilometers from the Poncol Train Station; 15 kilometers from the Tawang Train Station. Fresh air full of trees and clean water with an artistic system with drinking water quality. This place can be reached by public transportation modes Taxi, Go-jek, Grab or on foot. This condition makes Amanah village one of the favorite destinations for students who want to find a boarding house or a rented house. 22

Third, Physical capital. The physical facilities of the Amanah village are Large meeting rooms in the Amanah Center Building (GAC), office space, Pelita Bangsa Early Childhood School (PAUD), Baitussalam Mosque, 13 (thirteen) rented houses, integrated service post building. There have footsal field, 3 (three) badminton fields, 3 (three) meeting halls, 7 (seven) food stalls, 2 (two) laundry, and construction of a threelevel activity center building area of approximately $465 \mathrm{M} 2.23$

Fourth, Financial capital. Cash conditions of citizens' treasury are stored in various posts. The main post in the Environmental and

21 Interview with RW 04 secretary on November 15, 2018

22 Observation November 15, 2018

23 Interview with facility part RW 04 on November 20, 2018 
Clean Water Association (PLAB), which has a cash of approximately Rp. 75,000,000 and waste management of approximately $15,000,000$. Financial capital to support the implementation of the trust village is $20 \%$ of the cash owned or around Rp. 18,000,000.

Fifth, Social Capital. This capital is the key so that other capital can be used optimally. Based on the results of the Focus Group Discussion with residents structurally starting from the Rukun Tangga (RT) board of the Rukun Warga (RW), the Department of Education, community leaders, rented houses and boarding houses, stall owners and community representatives revealed that they strongly support the development of the Amanah village as an English village based on Islamic values. The forms of support are very diverse, starting with the naming of rented houses, the names of roads ready to be changed, and the names of merchandise. The willingness of citizens to start speaking English in daily interactions in the neighborhood of the Amanah village in Islamic education activities and daily activities. The Javanese phrase "Rukun agawe santoso" (familiarly made prosperous) is an expression of people's enthusiasm. Kampoeng Amanah has Pelita Bangsa Early Childhood Schools (PAUD) and Amanah Learning Center (AleC) 24 course institutions, an institution managed by the RW Amanah Cabinet education sector 4. English tutors are teachers who live in Kampoeng Amanah and a boarding house student and currently studying English in the English Masters Program at the Semarang District Court. In enhancing the management capabilities of the course institutions, Kampoeng

24 ALeC is a course institution established on 14 May 2017 and structurally under the management of RW 4 Kampoeng Amanah, Ngaliyan village. This institution has opened Islamic Religious Education courses, read and write Al Qur'an (BTQ), English, Arabic, Korean, and German. However, based on researcher's observations, only English courses have been conducted even though they do not yet exist. Interview with RW 04 Chair, November 21, 2018 
Amanah collaborated with the Walisongo Faculty of Education and Education (FITK) Dean and the Chair and Secretary of UIN Walisongo English Language Program on March 21, 201825

From the five capital it can be concluded that the potential of the Amanah village as an English village based on the Islamic Education is very good because all the potentials can be expected to support the development program. As a key factor is the support of social capital that already has an awareness of openness and cohesiveness to realize the Amanah village as a British village based on Islamic Religious Education.

Sixth, Religious Capital. This religious capital is the dominant one in Kampoeng Amanah and can be one of the characteristics of the community. The pattern of infrastructure development and community culture is very much influenced by religious values and can be seen as an advantage. The existence of religious learning and regular recitation in both the al Baitussalam mosque and in the Al Qur'an Education Park (TPQ) educational institutions and various takim prayer meetings for both fathers and mothers. The position of the mosque is right in the middle of the village. Ongoing religious activities include the study of Sunday Morning, Kliwonan, commemoration of religious holidays, Baitussalam's Qur'an Education Park (TPQ). Study of the books of jurisprudence, Sufism, and interpretation, including fath al qorib, nashoih al ibad, al Ihkam, bidayah al mujtahid. In the month of Ramadan there is always a qur'anic sermon for mothers (on the front porch) and continued with khotmul qur'an for fathers. Besides that, a study of Islam is also carried out in the afternoon and continued with ta'jil (open together).26

25 Interview with RW 04 Chair, November 21, 2018

26 Interview with the head of takmir of Baitussalam mosque, October 22, 2018 
Thus the potential of the Amanah village formed 6 potentials as follows.

CAPITAL OF KAMPOENG AMANAH

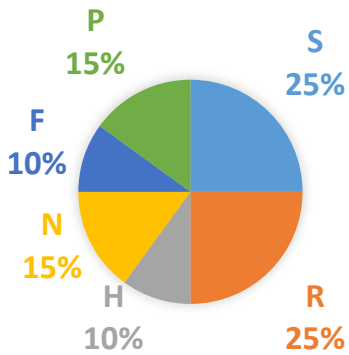

$\mathrm{R}=$ Religious Capital

$\mathrm{H}=$ Human Caital

$\mathrm{F}=$ Financial Capital

$\mathrm{N}=$ Natural Capital

$\mathrm{P}=$ Physical Capital

$\mathrm{S}=$ Social Capital

\section{Development Patterns and Maximizing Relgious Potential}

This trustful and tolerant culture has more strongly developed in the community of RW 04 Ngaliyan Village. The achievement gained was to become a representative of the Ngaliyan sub-district in a competition with the theme "Kampoeng Agamis and Toleran" to take part in the Semarang Town Great Competition which took place from October 2016 to 30 April 2017. The appointment of RW 4 as a contest participant with consideration of RW 4 has the criteria- evaluation criteria on the types of Kampoeng Agamis and Toleran competitions. This indicator is outlined in a RW 4 circular on October 6, 2016. The other contests are: Go Green Village RW 03, Clean village RW 5, Healthy Village RW 06, Active and Creative Village RW 01, and Peace and Safe Village RW 08. Understanding "Religious and Tolerant Kampoeng" is in line with the meaning of "Kampoeng Amanah", meaning that the village can be religious and the community can be tolerant when the community is also being trustful, namely trustworthy of God, 
trustworthy of fellow human beings, trustful of oneself and trustworthy of nature / environment.

Development is carried out in order to realize the village based on Islamic education, tolerant and English-language through several fields.

First, the education sector has established Pelita Bangsa Early Childhood Education (PAUD), course institutions (ALeC / Amanah Learning Center) and trainings. For PAUD, there are 93 students and 8 teachers. The pattern of Islamic education in PAUD has included religious material and English so that children are accustomed to religious lessons that use English. The formation of this culture is through the provision of story books, books on religious material in English and teacher training. This activity has brought enthusiasm and change to the community in carrying out teaching and learning activities. Whereas the Institute of Courses (ALeC / Amanah Learning Center) with the aim of increasing the role of RW in the field of education. This institution was inaugurated in conjunction with the inauguration of the Amanah Center Building (GAC) on May 14, 2017. The ALeC is intended to hold courses, such as the Read the Qur'an (BTQ), Islamic Religious Education, English, Arabic, Korean, and Languages German. Since its establishment this institution has only held English courses. The management of this institution is carried out by the Education Sector coordinator. Likewise Entrepreneurship Training. Training / training is part of the empowerment of the Kampoeng Amanah community, so that in the management structure of the Kampoeng Amanah RW 4 there is a Section in the Field of Training and Community Empowerment. This training field carries out educational programs and community empowerment through independent activities or collaboration with other parties. In addition, independent activities that are part of the Kampoeng Amanah program include drug prevention socialization, ODHA 
corpse screening (affected by HIV and AIDS), and regular religious studies. While entrepreneurship training activities, including training to make brains (collaboration with the Semarang City Fisheries Department), Micro Entrepreneur Training (PKK RW 4 collaboration with the Semarang City Cooperative and Micro Business Office), New Entrepreneur Training (collaboration with the Office of Manpower) Semarang City Work).27

Secondly, the Economic Development Sector held the Qordhul Hasan Program (savings and loan), coordinated 28 owners of rented houses and coordinated 24 other business owners. This program has run well and beneficial to the community. Whereas the Coordiation of Rented Houses / Boarding Houses and Stalls has been carried out continuously to monitor services for users of 28 rented owners in the trust village. 28 Until this research was conducted, several houses were built for boarding houses and rented houses, bearing in mind that this business was seen as safer as a form of investment that always experienced an increase land prices and houses in Kampoeng Amanah. The impact of the growth of rented houses and boarding houses in Kampoeng Amanah has indirectly increased the economy of the community where the needs of the residents are higher, such as the need for food, washing clothes, and daily necessities.

Third, the religious field. The development of Islamic Religious Education in this village is culturally and structurally through various religious activities that are held. Ongoing religious activities include the study of Sunday Morning, Kliwonan, commemoration of religious holidays, Baitussalam's Qur'an Education Park (TPQ). study of the books of jurisprudence, Sufism, and interpretation, including fath al qorib, nashoih al ibad, al

27 Interview with RW 04 Chairpersons 08 and 20 October 2018

28 Interview with the management of the economy on November 15, 2018; Location survey on October 19, 2018 
Ihkam, bidayah al mujtahid. In the month of Ramadan there is always a qur'anic sermon for mothers (on the front porch) and continued with khotmul qur'an for fathers. Besides that, a book study was also conducted in the afternoon and continued with $t a j i l$ (iftar Ramadan together). Besides that, the bazaar was held in the first week of Ramadan, a visit to an orphanage. As the end of the month of Ramadan activities is the collection and distribution of zakat through the Infaq and Sadaqah Zakat Waqf Institution (eLWaZIS) to the mustahiq zakat. Majlis Taklim (each RT, RWDanis) Majlis Taklim in Kampoeng Amanah consists of two levels, namely Majlis Taklim at RW level and Majlis Taklim at RT level. Majlis Taklim at the RW level facilitates religious activities that include Muslim women in RW 4 and RT 3 RW 12. The majlis taklim is called "Darun Nisa" 'or often abbreviated as Danis. Whereas the majlis taklim at the RT level has their own group and majlis name. Masjlis Taklim Darun Nisa 'is an organization under the Working Group I (now using the term Member 1) PKK RW 4. ${ }_{29}$ Rebana Group as an expression of art has established two groups namely adolescent tambourine groups and tambourine groups of Baitussalam Mosque worshipers under the name Rebana Qotrun Nida Group and Rebana Qotrun Nida junior Group group has achieved achievements in several events held at the Semarang City Hall Building. In this religious activity, gradually inclusion of the use of English as a language of communication and awareness of the importance of English for the development of society. 30 This can be realized because of two main factors, namely the open nature of the community and the large number of UIN Walisongo 2018

29 Interview with the head of takmir of Baitussalam mosque, October 22,

30 Interview with the head of takmir of Baitussalam mosque, October 22, 2018 
students who live in the village of Amanah. The situation is gradually affecting the community in everyday life. 31

The pattern of development that makes religious activities as the main driving force is an unusual thing to do in an urban environment. Religious Education activities in an urban environment that is almost equal to religious activities in the Islamic boarding school environment. There is the yellow book recitation, Al Qur'an study, general recitation and Islamic art activities. This religious activity spearheaded the community of Kampoeng Amanah in realizing a language village based on Islamic Religious Education. The pattern of community development using religious power can usually succeed in a homogeneous environment such as in a pesantren environment, but in the urban environment it can also be implemented in the village of Amanah where the community is heterogeneous.

\section{Conclusion}

The development of the Amanah Kampoeng community, which is located near the campus as a language camp based on Islamic education, is carried out in stages by involving the whole society. The success of this development is unusual because the community is heterogeneous. But this can be realized in the village of Amanah by maximizing religious potential and the support of 5 other potentials namely human capital, social capital, natural capital, physical capital and financial capital. Islamic Religious Education has given a dominant influence in the development of this village into a British village based on Islamic Religious Education which is close to campus.

31 Interview with RW 04 Ngaliyan chairman of stairs 20 October 2018 


\section{Bibliography}

"About the OECD - OECD." Accessed on 22 Oktober 2018. http://www.oecd.org/about/.

AP, Pundarika. "Banjar." Boedaja Bali (blog), 2 September 2012. https://boedajabali.wordpress.com/2012/09/02/banjar/.

"Arti kata potensi - Kamus Besar Bahasa Indonesia (KBBI) Online." Accessed on 1 October 2018. https://kbbi.web.id/potensi.

Asian Productivity Organization. Potential of Social Capital for Community Development. Japan: APO, 2006.

Bailey, William C. "Poverty, Inequality, and City Homicide Rates. Some Not So Unexpected Findings." Criminology 22, no. 4 (November 1984): $\quad 531-50$. $\quad$ https://doi.org/10.1111/j.17459125.1984.tb00314.x.

DFID. "Sustainable Livelihoods Guidance Sheets," 1999. http://www.livelihoodscentre.org/documents/20720/100145/Sustai nable+livelihoods+guidance+sheets/8f35b59f-8207-43fc-8b99df75d3000e86.

Engbersen, Godfried. Cultures of Unemployment: A Comparative Look at Long-Term Unemployment and Urban Poverty. Amsterdam: Amsterdam University Press, 2006.

Field, John. Social Capital. London; New York: Routledge, 2003.

Giddens, Anthony. Modernity and Self-Identity: Self and Society in the Late Modern Age. Reprint. Cambridge: Polity Press, 2003.

Hadi, Agus Purbathin. "Tinjauan terhadap berbagai program pemberdayaan masyarakat di indonesia." Yayasan Agribisnis/Pusat Pengembangan Masyarakat Agrikarya (PPMA), 2009.

Hendrawaty, Nurmala, dan Tri Angkarini. "THE ACQUISITION OF ENGLISH AS A FOREIGN LANGUAGE IN PARE EAST JAVA (KAMPUNG INGGRIS).” Deiksis 05 (2013): 8.

Lin, Nan, Karen S. Cook, dan Ronald S. Burt, ed. Social capital: theory and research. Sociology and economics. New York: Aldine de Gruyter, 2001.

Longman, Pearson. Longman Dictionary of American Engish. Edinburgh: Pearson Education Limited, 2009. 
McIntyre, Alice. Participatory action research. Qualitative research methods 52. Los Angeles: Sage Publications, 2008.

Noor, Munawar. "PEMBERDAYAAN MASYARAKAT." Civis, no. 2 (2011): 13.

Pete, Engardio. "How China and India Are Revolutionizing Global Business." New York: McGraw-Hili, 2006.

Prawoto, Nano. "Memahami Kemiskinan Dan Strategi Penanggulangannya." Jurnal Ekonomi dan Studi Pembangunan 9, no. 1 (2009): 58-68.

Prihadhi, Endra K. My Potency. Jakarta: Elex Media Komputindo., 2004.

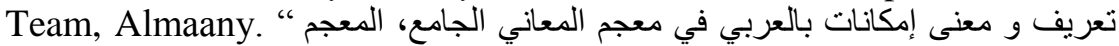
1 الوسيط ،اللغةً العربية المعاصر - معجم عربي عربي - Accessed on 20 October $20^{\text {th }} 2018$. https://www.almaany.com

Vitasurya, Vincentia Reni. "Local Wisdom for Sustainable Development of Rural Tourism, Case on Kalibiru and Lopati Village, Province of Daerah Istimewa Yogyakarta." Procedia - Social and Behavioral Sciences $216 \quad$ (Januari 2016): 97-108. https://doi.org/10.1016/j.sbspro.2015.12.014.

Wiyono, Slamet. Managemen Potensi Diri. Jakarta: PT Grasindo, 2006. Yasa, Murjana. "Penanggulangan kemiskinan berbasis partisipasi masyarakat di Provinsi Bali." Input: Jurnal Ekonomi dan Sosial 1, no. 2 (2008). 